CPE

4,2

\section{4}

Received 12 November 2021 Revised 12 November 2021 Accepted 12 November 2021

\title{
Understanding the China miracle from the paradigm of realm economics
}

\author{
Xiaodong Chen \\ Institute of Industrial Economics, Chinese Academy of Social Sciences, Beiïng, China
}

\section{Abstract}

Purpose - The core of the micro-macro paradigm of mainstream Western economics is the assumption that a rational economic man with complete freedom of economic behaviors living in a fully competitive, free-market economy pursues maximum personal benefits. The purpose of this paper is to show the reasons for failure of mainstream Western economics explaining the "mystery of China's economic growth" and the necessity of understanding the mystery from the paradigm of realm economics.

Design/methodology/approach - The system of socialism with Chinese characteristics led by the Communist Party of China (CPC) and the local governments that play a crucial role in the reform and openingup has the realm attribute. It is necessary to develop a new paradigm for realm economic analysis and promote the creation of new economic globalization and international political and economic order.

Findings - According to the fourth plenary session of the 19th CPC Central Committee, "Since the New China was founded 70 years ago, our Party has led our people to create the rarely-seen miracle of rapid economic development and miracle of long-term social stability". The authors find that it is effective and necessary to explain the miracle of China's economic growth from the paradigm of realm economics.

Originality/value - As proven by practice, the system of socialism with Chinese characteristics and the governance system of China are guided by Marxism, rooted in China with a deep Chinese cultural foundation, and sincerely supported by the people.

Keywords Micro-macro paradigm, New economic paradigm, Realm attribute, Chinese characteristics Paper type Research paper

According to the fourth plenary session of the 19th Communist Party of China (CPC) Central Committee, "Since the New China was founded 70 years ago, our Party has led our people to create the rarely-seen miracle of rapid economic development and miracle of long-term social stability. China has stood up, grown prosperous, and become stronger. As proven by practice, the system of socialism with Chinese characteristics and the governance system of China are guided by Marxism, rooted in China with a deep Chinese cultural foundation, and sincerely supported by the people. These systems are of strong vitality and huge strength, which can facilitate the continuous progress of the country with a population of nearly 1.4 billion people and ensure the realization of the two centenary goals toward the rejuvenation of the Chinese nation that has a civilization of more than 5,000 years" (The Central Committee of the Communist Party of China, 2019). The two miracles of China's economic developments remain to be the mysteries that cannot be solved with the micro-macro paradigm of the Western mainstream economic theories. In the paradigm or framework of mainstream Western economic theories, an imaginary unitary symbol system often replaces a true

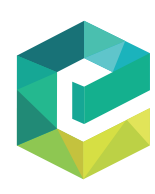

China Political Economy Vol. 4 No. 2, 2021 pp. $214-223$ Emerald Publishing Limited 2516-1652 DOI 10.1108/CPE-11-2021-0016
(C) China Social Science Review. Published in China Political Economy. Published by Emerald Publishing Limited. This article is published under the Creative Commons Attribution (CC BY 4.0) licence. Anyone may reproduce, distribute, translate and create derivative works of this article (for both commercial and non-commercial purposes), subject to full attribution to the original publication and authors. The full terms of this licence may be seen at http://creativecommons.org/licences/by/4.0/legalcode. Originally published in Simplified Chinese in China Social Science Review.

This paper received funding from a major research project of the National Social Science Foundation of China (grant agreement No. 18vxk002). 
pluralist behavioral world, which is prone to lack explanatory power. In 2020, the global economy was hard hit by the coronavirus disease 2019 (COVID-19) pandemic. Many developed or developing countries that follow the Western road to modernization suffered a decline in macro- and micro-economies. In contrast, China was the only major economy in the world that achieved positive economic growth. This proves the superiority of the socialist system again and has a significant influence on the global reconstruction of economics. Thanks to historical and cultural traits formed in the past thousands of years and New China's extraordinary practice of exploring the socialist development path over the past more than 70 years, the Chinese economy's microscopic entities and macroscopic situation are distinct, rich and diversified. Understanding the realm attribute of the Chinese path and achievements requires that economics research paradigms can effectively interpret complex phenomena and cover all aspects of the unbalanced development of China as a giant economy (Jin, 2019a).

\section{The realm paradigm contributes to understanding the real world in multiple dimensions}

Excellent theories are generated from great practice. In the 30 years from the founding of the New China to the eve of the reform and opening-up, the mainline of the Chinese economic theoretical system consists of socialist political economics with Soviet-type economic planning practices as the research object and the capitalist part of political economy based on Capital authored by Karl Marx. The main thread of the research paradigms combining with the two categories of economic thoughts is reflected in the historiography paradigm structure based on historical logic. Since the reform and opening-up, the research results of mainstream Western economics have continually integrated into socialist economic research, and the neoclassical economics comprising Western microeconomics and macroeconomics has gradually become a mainstream research paradigm. The core idea of neoclassical economics is that an atomized individual enjoys sufficient economic liberty and lives in a fully competitive, free-market economy, pursuing his/her maximum profits based on reason. A perfect utopia is derived from an imaginary absolute space in an economic world conceived according to liberate neoclassical economics. That is a unitary world governed by a single law that everyone acts freely following the principle of economic rationality. Although the micromacro paradigm in mainstream economics does not deny the differences among people in the actual world, it ignores the different attributes of social men and advocates the universality of the idea that human nature is selfish. Although this paradigm does not deny the heterogeneity of real enterprises, it assumes that the nature and behavioral objectives of enterprises are pursuing profit maximization (Jin, 2020). Self-interested behavior of homogeneous microeconomic entities operates in a homogeneous space without differences, which is regarded as an undoubtedly "self-evident truth" in "modern economics". Since this is similar to the "pure ideal state" achieved under natural science laboratory conditions, this is called "science". Regardless of essential distinctions and dynamic changes of basic systems, mainstream Western economics use increasingly complicated mathematical derivation methods to interpret assumptive economic questions that do not exist or are unlikely to exist or to demonstrate common-sense conclusions. The maturity and progress of economic thoughts are reflected by increasingly abstract and analogical economic models in more attractive and dazzling forms rather than a more profound, comprehensive and detailed systematic interpretation of economic and social changes in reality.

Since the marginal revolution against the labor theory of value, the evolution of modern economics toward mathematical economics has been continually criticized by the wise, who jokingly called it "blackboard economics". The deductive method imitating Euclidean geometry has become the main method of modern mainstream economics. Steps include making up some hypotheses intellectually, building an abstract mathematical model,
China miracle and realm economics 
solving it like mathematics and physics, and finally drawing a "satisfactory" conclusion (Chen, 2019). Friedman (1953) once sharply pointed out that "the more significant the theory, the more unrealistic the assumptions". According to Lucas (1983), the results of those models are not the actual economic world itself, and their pseudo-relevance lies in "simulating the time series of an actual economy through time series approximation". As a result, "the progress of economic thoughts means increasingly good, abstract and analogical economic models instead of a well-written description of the world". Just as Engels (2012) pointed out in Anti-Duhring, the abstract role of quantitative relations in mathematics is that "to study those forms and relations from their pure state, they must be completely divorced from their own content by putting aside content as something insignificant". If mainstream economics are continually enthusiastic about delicate assumption and deduction tools, it will be more challenging to accurately explain actual economic and social developments. As mainstream economics "deduce the laws on man in society by proceeding from the rationaleconomic man as an extremely stable and highly simplified human nature" (Schumpeter, 1991), all the areas of social sciences fall into the analytical paradigm of the "rational economic man".

The "micro-macro" paradigm of mainstream Western economic theory disregards the intrinsic social effects of various social relations, such as values, culture, institutions and the environment, on men in real societies and assumes that the social environment where men produce and live is an absolute space to ensure that its assumptions can lead to the results of general equilibrium and further render that the claimed laws have strict logic and universality. "Blackboard imperialism" invades authentic rationality with instrumental rationality, overriding the real world full of individuality and diversity. According to Jin Bei's criticism (2018), the unreasonableness lies in the fact that "despite a perfect appearance of formal logic, economics have their inherent logic flaws. That is, logical deduction relies excessively on assumptions, and some assumptions are divorced from reality or even ignore the facts. They tend to follow instrumental rationality at the cost of authentic value rationality" Jin (2018). Jin (2020) proposes using the realm paradigm in economics to remedy the flaws in mainstream Western economics, and the description of a "realm" can be abstracted in three main dimensions. The first dimension is economic rationality, which is the most fundamental assumption of the "micro-macro" paradigm. Economic rationality is abstracted as instrumental rationality in economics and assumes that humans seek gains and avoid losses. However, only this dimension is not enough to honestly portray human rationality or behavioral orientation. Thus, the second dimension, that is, value culture, is required. The nature of humans as a species is that humans have consciousness and thought and can make and use tools purposefully. Different ideas, behaviors and tendencies of people directly result in different acts of each individual, and people cannot be fully abstracted as men without differences in specific analysis. This cannot be excluded from the paradigm analysis framework. The third dimension is the systematic pattern. The formation of systems is not the result of rational construction but structural accretion in the course of historical development. And systems are also diverse. If economics is limited to the only dimension of economic rationality, the ability of the "micromacro" paradigm to interpret the facts will reduce gradually. Further study on cultural value, systematic patterns and other issues based on rationality is the ultimate manifestation of economics as a discipline of knowledge and practice. Observing and understanding reality in various dimensions is an inevitable development direction of economics. There are different enterprises and groups in different countries or regions, which have different behavior patterns and are subject to different social systems. The mixed concretization can be regarded as a "realm" regarding the research object as a whole. By expanding the commitment paradigm of the economic research from the "micro-macro" perspective to the realm perspective, realm economics develops from simple logical 
abstraction to concretization. Adding new complicated dimensions to the previous simple paradigm framework is conducive to better describing and understanding reality.

\section{The realm attribute of socialism with Chinese characteristics}

According to the homogeneous space portrayed based on the "micro-macro" paradigm of Western mainstream economics, in the eyes of the Western world, especially the United States, all countries in the world should be homogeneous and implement a capitalist system. As Werner Sombart said, European immigrants gave up whatever they could give up to go to the USA and created a so-called brand new life on the principle of pure reason. That is because "there is no other country in the world like the USA where people brazenly show their greediness for monies, and the ultimate goal of each economic activity is to make profits, to make money at any cost. Here, people work hard day and night for money. The insatiable appetite for profits will not stop until the last breath of life. In the USA, people know nothing about any way of making a living other than capitalism. It is out of pure economic rationality never experienced in European countries that people's desire to gain profits is satisfied like never before. Even if the path to capitalism is paved with countless corpses, this cannot stop the advancing paces of capitalism" (Sombart, 2013).

Just like the biological world described in Darwin's theory of evolution, the real economies under realm economics can be classified as different individualities and "realm states" with distinctive features. In terms of logic architecture, the realm analysis paradigm first acknowledges that the realm attribute is jointly decided by homogeneity and heterogeneity, and it adopts the realm attribute as a basic paradigm mode for observing the economic world. Various social systems in human history were not conceived and established based on "rationality" but a result of certain social entities' collisions, constant practices, trials and selections. The choice of different rational judgments ultimately depends on the essential development requirements of predominant social entities. Therefore, the economic world is inevitably diverse; the social and economic systems of different countries cannot follow the same pattern, and the optimal system in absolute space is nonexistent. China's social ecology has a unique realm attribute different from that of any other country.

Among numerous realm features with Chinese characteristics, the biggest feature is the centralized and unified leadership of the CPC, serving the people wholeheartedly. The socialism with Chinese characteristics led by the CPC is a choice of history, and the strong social organization ability and national mobilization ability thus formed are necessary conditions for China to take extraordinary measures and policy arrangements in response to various sudden events (Jin, 2019b). Upon the outbreak of the COVID-19 pandemic in 2020 and other major public emergencies, the Communist Party of China always put in the first place the people's life security and vital interests, which fully showed the Party's fundamental purpose of serving the people with heart and soul. "All speeches and behaviors of the Party members must be in line with the maximum interests of the overwhelming majority of the masses, with the support by the overwhelming majority of the masses as the highest standard" (Mao, 1991). The CPC adheres to the mass line of "staying with and listening to the masses, trusting and relying on the masses" and makes sure that the Party's policies and guidelines always reflect the will of the people and safeguard the interests of the people (Gu and Chen, 2020). Ever since its birth, the CPC has always played a decisive role in organizing and mobilizing the public at all stages of China's revolution and during the country's socialist construction. This is something that any political party in any nonsocialist country can never achieve. The Party's leadership over all work includes its leadership over economic development. To be specific, the Party directly formulated and implemented basic lines and made all necessary system arrangements during the Chinese revolution, construction, and reform and opening-up. In particular, the Party is currently implementing new-era
China miracle and realm economics 
CPE

4,2

218

development concepts in an all-around way. Unlike the "government" regulation mechanisms and their roles described in the "micro-macro" paradigm, the Party's leadership is "supermacro control" in terms of status and functionality and exerts comprehensive influence. New China's socialist economic development and industrial development in the past more than 70 years after its founding have innovative and exploratory attributes, which are unmatched by any other country. The unique realm attribute of New China regarding its robust growth is the conditions and foundation that can hardly be imitated or replicated by other countries. There are no so-called optimal models for each country's political system, economic system and policy arrangements. Those that can effectively adapt to the local situations in different historical conditions are the most realistic rational choices.

Faced with major changes unfolding in the world, something unseen in a century, the world has entered into a stage of turbulence and revolutions. It is increasingly difficult for the "micro-macro" paradigm to interpret various economic phenomena in human society. The economic world it depicts is unitary and monotonous, and many significant realities that go against the principles of this paradigm are often regarded as anomalies, or denied, or deemed unexpected "black swans" or "grey rhino" that no rules can explain. According to the "micromacro" paradigm, the miracle of long-term and high-speed sustained development of the economic society of socialism with Chinese characteristics runs counter to theoretical normal, which should be excluded before considering China's social system as one of the mainstream social systems in the world.

Economic globalization means factor flow, smooth trade and investment fusion among various economies worldwide, but this does not necessarily lead to the homogenization and structural assimilation of all such economies. Given spatial differences of economic activities resulting from geological, cultural and institutional factors, economic globalization cannot exclude the pluralism and diversity of economic development. Those different economic worlds with unique characteristics are closely correlated in good and bad times. Even for people trained and developed in the "micros-macro" paradigm, when they take a look at the whole world, they will find, just as Joseph E. Stiglitz did before, that "another world is possible" amidst the turbulence of old institutional structures. The socialism with Chinese characteristics and its economic system is the "another world" in the new pattern of globalization distinctive from the Western world led by the USA.

According to the principle of cultural diversity, it may be asserted that there are many more "other worlds" with different properties and characteristics apart from China. But no one can deny that socialism with Chinese characteristics and its economic system plays an important role in the diversified pattern of economic globalization, and the globalized world economy will become more colorful and promising due to the existence of the socialist economic system with Chinese characteristics. Only when economic globalization accommodates more third-world countries, including China, and becomes more inclusive will the world's economic development be more sustainable. China's economy will be increasingly similar to other economies with the deepening of economic globalization, but the differences will not be erased entirely. Meanwhile, economic globalization will not be less vigorous due to reduced differences.

According to the analysis paradigm of realm economics, each country's economic development is based on the requirements of its society and has unique realm attributes. The USA implements laissez-faire capitalism, Germany the social market economy system and China the socialist system with Chinese characteristics. These long-developed institutions with those unique development paths and economic models are based on their respective profound cultural and historical backgrounds and choices of values. In the process of world history, national entities of numerous market economies have the requirements for fair competition and mutually beneficial cooperation. Therefore, the interconnection of economies with different realm attributes is imperative, and the hegemonistic "long-arm jurisdiction" 
will inevitably not prevail over time. In the negotiation and coordination among countries, there is a need for all participants to mutually benefit each other in order for globalization not to be reversed. The diversified structure and the trend of diversity for economic globalization require countries to follow the Five Principles of Peaceful Coexistence and work together on the construction of a community with a shared future for mankind.

\section{Special roles of local governments in regional economic development}

The relationship between "government and market" has always remained a core issue discussed in mainstream Western economics concerning growth theory. Through a review of the development history of Western economic thoughts, the government is supposed to play the roles of "night watchman" and "stopgap" in economic growth. Although the government sometimes appears at the center of the economic arena, it never plays the leading role in economic development. Within more than four decades, starting from the reform and opening-up, China has transitioned from a planned economy to a socialist market economy and maintained sustained rapid economic growth. And this economic wonder continues despite aggravated uncertainties, which can hardly be explained by the framework of the "micro-macro" paradigm.

During the top-down progressive reform that China initiated in 1978, the Central Committee of the CPC has generally left much room for local governments to adapt to local conditions regarding proposing reform directions and principles at the state level, taking into account local historical traditions, cultural differences and development situations. This interregional decentralized experimentation based on the market-oriented reform trend, figuratively expressed as "crossing the river by feeling the stones", proves the correct choice for China to address the "Hayek's knowledge problem" (Papke, 2001; Xie, 2018) during its progressive reform. As natural science only reflects the laws of motion of matter in the organic world (including biological attributes of mankind) or the inorganic world in nature, the laws governing the market economy are not the "universal laws" packaged by the "micro-macro" paradigm of mainstream Western economics. Under both socialist and capitalist conditions, the market economy is a way and means by which a certain social subject allocates resources for material production and has distinctive historical and cultural characteristics. The efficiency of a market economy depends on its compatibility with the economic social environment. The relationships among market economy, production conditions, and the social environment and the evolution of such relationships are not governed by a universal abstract matching model divorced from those relationships. The Western mainstream economic theories used to argue that the dual-track price reform adopted at the initial stage of China's transition is the worst way (Murphy et al., 1992). However, during the ongoing market-oriented reform, China continually adjusted the resource allocation methods compatible with the public ownership system and realized the largest-scale economic growth since the Industrial Revolution in Great Britain (Maddison, 2008). Western mainstream economic theories always tried to reveal the "mystery of China's economic growth", but they failed due to the limitations of the "micro-macro" paradigm.

Specifically, how do we view the imbalance in China's regional development under the central government's unified macro-control policy? If the comparative advantages of various resources and factors are the cause of regional economic development disparities, how do we explain the significant differences among regions with similar starting conditions or within any local economy? Within the framework of the conventional "micro-macro" paradigm, many analytical factors might be not "causes" but "results" of economic development. In the process of China's reform and opening-up, though the roles of the market or entrepreneurs are admittedly important, the key role of government, especially local government, cannot be ignored. Given that in China, many provinces have jurisdictions and economic volumes that 
CPE

4,2

220

reach or even exceed those of a European country, it is impossible to ignore or discard the special realm attributes of China's economic development, which are highlighted by unbalanced regional development, during the analysis of regional economic development.

Over the more than 70 years since the founding of New China, the government-led continual economic growth has been an objective fact though the "government-led" extensive economic growth model has often drawn criticism for its serious structural imbalances (Wu, 2008). The government-led economic growth is an inevitable choice for China to effectively avoid the pitfall of the "cumulative circle and causation theory" (Myrdal, 1957) during its system transition, so it is impossible to rush to the conclusion groundlessly that "the economy would fare better without government leadership". The history of the world's economic development and reality have proven that any large economy's government plays a crucial role in social development, including the countries with the highest living standards like Nordic countries and fastest-growing economies like China (Stiglitz, 2013). The side effects of the government-led growth model are attributed to the government pulling ahead of historical and cultural stages, trying to substitute the market or showing no respect for market entities (Liu, 2020).

In Western mainstream economic theories, the government generally comes on the stage at the time of "market failure" or when the economy is mired in the dilemma of "Nash equilibrium". Any microscopic market entity is neither motivated nor able to get out of the dilemma, and then local government's intervention becomes the only feasible way and choice to get over the dilemma (Chen and $\mathrm{Hu}, 2014$ ). In addition, in specific regions without the "gene" of market economy and at specific development stages, government tends to play a decisive role in the formation of market entities and construction of the market system (Chen, 1996). Therefore, as the "linker" between an incomplete planned economy and an incomplete market, the government's influence cannot be substituted by any other entity, and local government plays the role of market entity unconsciously in the market-oriented reform ( $\mathrm{Li}$, 2004). The reason why "the mystery of China's economic miracle" arouses extensive attention is the peculiarities during the country's economic growth. At the beginning of its reform and opening-up, China had no absolute advantages in resources, talent, technology and other aspects. Its per capita income stood at a relatively low level worldwide. Also, it ranked low in terms of the institutional quality and governance capacity measured according to Western standards (Allen et al., 2005). Based on the "micro-macro" paradigm of mainstream Western economics, China would not achieve the miracle of sustained economic growth that can go down in history. However, the facts were the opposite. It is worth noting that for pursuing many more local economic development opportunities, Chinese local governments take full advantage of their critical position and detached identities in regional economic societies to mobilize resources as much as possible and promote regional economic growth. The role of local governments in sparing no effort to promote economic development is rarely seen worldwide. According to mainstream Western economic theories, excessive government involvement in economic activities in transition countries was the main reason why these countries were in economic trouble, and governments were even considered to be the "number one killer" of economic growth - an incompetent, corrupt, and inefficient government is a fatal impediment to economic growth (Easterly, 2001). The government's active role in China's economic development over more than 70 years after the founding of New China is incompatible with the "micro-macro" paradigm.

The appeal of the "mystery of China's economic growth" lies in the fact that although the government administration system influences economic growth like the property rights system (Shleifer and Vishny, 1993), the governance system with Chinese characteristics is the very foundation for the Chinese government to spur its own economic development actively. The Chinese governments, including local governments, play the following roles: the driver of system transformation during the transition period; the allocator of significant resources on 
the market; the leader of social and cultural change; and the direct promoter of economic growth. As government plays so many roles, the single "micro-macro" paradigm in mainstream Western economics can hardly conduct a comprehensive and thorough investigation, and a lot of paradoxes that are confounding for Western scholars arise. The Chinese government as a "visible hand" does not fall within the framework of Western mainstream economic theories, and the "government-market" relationship is much more colorful than that described in mainstream Western economic theories. In China, governments from central to local governments at various levels are deeply involved in economic and social reform, development and stability. The particularity of China's reform and opening-up is that governments play a vital role in improving the socialist market economic system while facing a strategic mission of realizing the modernization of the national governance system and governance capacity. The only way to solve the mystery of China's economic growth is researching China's rich practices in "giving better play to government functions" on the premise that the market plays a decisive role in resource allocation and accurately identifying the realm attribute of governments, including local governments, in promoting China's economic development, which explains economic development disparities among different regions and lays a solid academic foundation for addressing the principal contradiction involving unbalanced and inadequate development in the new era.

\section{Conclusion}

In today's world replete with changes and turbulences, the "micro-macro" paradigm in mainstream Western economics can hardly explain various economic phenomena and activities existing in human society. However, the mainstream economic paradigms, which are deeply rooted in Western society, still stubbornly cause trouble in international negotiations between China and the Western countries, especially negotiations on US-China trade disputes, and become the theoretical basis for the "long-arm jurisdiction" of hegemonism. In their opinion, other economies and the global economy shall all follow the Western model; otherwise, those economies will be labeled "non-market economies" and excluded from economic globalization. However, cultures are diverse, and the world is pluralistic. The world economy is nonhomogeneous, and different countries have different economic structures. As an old Chinese saying goes, "all living creatures grow together without harming one another; ways run parallel without interfering with one another." The social and economic systems and market economic orders of various countries established based on the respective national conditions for different histories and cultures should be treated with respect.

The economic development of New China with unique attributes has changed not only the old image of China but also the world. In the context of a new round of scientific and technological revolution and the development of emerging industries, China is making a positive contribution to economic globalization. Guided by the "harmony in diversity" thought proposed by ancient Chinese philosophers, China is promoting major changes in the pattern of economic globalization from its connection with the world to its integration into economic globalization. In particular, China is now implementing the "Belt and Road Initiative" to promote the construction of a new international economic order based on economic globalization. The academic discussion on realm economics as a new analysis paradigm is now well-timed.

\section{References}

Allen, F., Qian, J. and Qian, M.J. (2005), "Law, finance, and economic growth in China", Journal of Financial Economics, Vol. 77 No. 1, pp. 57-116. 
CPE 4,2

Chen, T.X. and Hu, J. (2014), "Xingzheng shenpizhong de ziyou cailiang xingwei yanjiu [on the discretionary behavior of administrative approval]", Zhongshan Daxue Xuebao (Shehui Kexue Ban) [Journal of Sun Yatsen University (Social Science Edition)], Vol. 54 No. 2, pp. 152-166.

Easterly, W.R. (2001), The Elusive Quest for Growth: Economists' Adventures and Misadventures in the Tropics, MIT Press, Cambridge, MA.

Engels, F. (2012), "Philosophy", Central Compilation and Translation Bureau, Makesi engesi xuanji: disanjuan [Marx and Engels Selected Works: Volume III] (Chinese translation edition translated by Central Compilation and Translation Bureau), People's Publishing House, Beijing, p. 413.

Friedman, M. (1953), Essays in Positive Economics, University of Chicago Press, Chicago, p. 14.

$\mathrm{Gu}$, X.L. and Chen, X.D. (2020), "Goujian yi renmin wei zhongxin de guojia zhili jiazhi tixi [constructing a people-centered value system of national governance]", Zhongzhou Xuekan [Academic Journal of Zhongzhou], Vol. 42 No. 11, pp. 65-69.

Jin, B. (2018), "Guanyu kaituo shangyu jingjixue xinxueke yanjiu de sikao [reflections on developing new disciplines of business realm economics]", Quyu Jingji Pinglun [Regional Economic Review], Vol. 33 No. 5, pp. 1-13.

Jin, B. (2019a), "Shilun jingjixue de yuguan fanshi-jianyi jingjixue zhongguo xuepai yanjiu [on the realm paradigm of economics - discussion on the Chinese school of economics]", Guanli Shije [Management World], Vol. 35 No. 2, pp. 7-23.

Jin, B. (2019b), "Zhongguo jingji 70 nian fazhan de xinguancha [a new observation on 70 years of China's economic development]", Shehui Kexue Zhanxian [Social Science Front], Vol. 42 No. 6, pp. 1-11.

Jin, B. (2020), "Yi xinfanshi siwei renshi he yingdui jingji quanqiuhua geju de xinbianhua [understanding and responding to emerging changes in economic globalization with a new paradigm thinking]", Jingii Yu Guanli Yanjiu [Research on Economics and Management], Vol. 41 No. 3, pp. 3-10.

Li, Y.P. (2004), "Dangqian zhidu kuangjiazhong difang zhengfu de xingwei fenxi [an analysis on the behavior of the local government under the current institutional framework]", Dangdai Jingji Kexue [Modern Economic Science], Vol. 26 No. 5, pp. 47-51.

Liu, Z.Y. (2020), "Zhuanxingqi diqu chuangxin xitongzhong de 'Shuangzhuti'-jiyu zhengfu yu qiyejia de yanhua boyi [the "double subject" in the regional innovation system during the transformation period: the evolutionary game based on the government and the entrepreneur]", Jingji Wenti [On Economic Problems], Vol. 42 No. 5, pp. 113-122.

Lucas, R.E. Jr (1983), Jingii Zhouqu Lilun Yanju [Studies in Business-Cycle Theory], (Chinese translation edition Translated by Zhu, S.L.), The Commercial Press, Beijing, p. 255, p. 258.

Maddison, A. (2008), Zhongguo jingji de changqi biaoxian-gongyuan 960-2030 nian [Chinese Economic Performance in the Long Run: 960-2030 AD], (Chinese translation edition translated by Wu, X.Y. and Ma, D.B.), Shanghai People's Publishing House, Shanghai.

Mao, Z.D. (1991), “On coalition government”, Publishing Committee of Selected Works of Mao TseTung of the Central Committee of the Communist Party of China, (Ed.) Maozedong xuanji: disanjuan [Selected Works of Mao Tse-tung: Volume III], People's Publishing House, Beijing, p. 1096.

Murphy, K.M., Shleifer, A. and Vishny, R.W. (1992), "The transition to a market economy: pitfalls of partial reform”, The Quarterly Journal of Economics, Vol. 107 No. 3, pp. 889-906. 
Myrdal, G. (1957), Economic Theory and Underdeveloped Regions, Gerald Duckworth, London.

Papke, G. (2001), "Knowledge issues and their Impact", in Papke, G. (Ed.), Zhishi, Ziyou Yu Zhixu [Knowledge, Freedom and Order], (Chinese translation edition translated by Huang, B.Y.), China Social Science Press, Beijing, pp. 1-32.

Schumpeter, J. (1991), Jingii Fenxishi: Diyijuan [History of Economics Analysis: Volume I], (Chinese translation edition translated by Zhu, Y., Sun, H.S., Li, H. and Chen, X.L.), The Commercial Press, Beijing, p. 204.

Shleifer, A. and Vishny, R.W. (1993), “Corruption”, The Quarterly Journal of Economics, Vol. 108 No. 3, pp. 599-617.

Sombart, W. (2013), Weishenme Meiguo Meiyou Shehui Zhuyi [Why is There No Socialism in the United States], (Chinese translation edition translated by Wang, M.L.), Publishing House of Electronics Industry, Beijing, p. 4.

Stiglitz, J.E. (2013), Bupingdeng de daijia [The Price of Inequality], (Chinese translation edition translated by Zhang, Z.Y.), China Machine Press, Beijing, p. 156.

The Central Committee of the Communist Party of China (2019), Zhonggong zhongyang guanyu jianchi he wanshan zhongguo tese shehui zhuyi zhidu tuijin guojia zhili tixi he zhili nengli xiandaihua ruogan zhongda wenti de jueding [Decision of the Central Committee of the Communist Party of China on Several Major Issues of Adhering to and Perfecting the Socialist System with Chinese Characteristics and Promoting the Modernization of the National Governance System and Governance Capability], People's Publishing House, Beijing, pp. 2-3.

Wu, J.L. (2008), Zhongguo Zengzhang Moshi Jeuze [The Choice of China's Growth Model], Shanghai Far East Publishing House, Shanghai.

Xie, Z.G. (2018), "Hayeke zhishi wentizhong de xinxi yu zhishilun [information and epistemology in Hayek's knowledge problem]", Renwen Zazhi [The Journal of Humanities], Vol. 44 No. 6, pp. $42-50$.

\section{Corresponding author}

Xiaodong Chen can be contacted at: njcxd@aliyun.com
China miracle and realm economics 